\title{
Teeth and their Secrets - Forensic Dentistry
}

Karanprakash Singh ${ }^{1 *}$, Chitra Anandani' ${ }^{2}$, RamanPreet Kaur Bhullar ${ }^{1}$, Anil Agrawal ${ }^{3}$, Harshvardhan Chaudhary ${ }^{2}$ and Ankur Thakral $^{4}$

${ }^{1}$ Genesis Institute of Dental Sciences and Research, Ferozepur, India

${ }^{2}$ Pacific Dental College and Hospital, Debari, Udaipur, Rajasthan, India

${ }^{3}$ New Horizon Dental College \& Research Institute, Sakri, Bilaspur, Chattishgarh

${ }^{4}$ A.B Shetty Memorial Institute of Dental sciences, Karnataka, India

\begin{abstract}
In addition to their important functions in mastication and esthetics, the teeth may also be used as a weapon and under certain circumstances, may leave information as to the identity of the biter. The individuality of the human dentition frequently allows the Forensic Odontologist to reach a strong opinion of association in cases of identification and bite mark analysis. Such analysis can often be useful during the investigation of violent crimes, especially those involving sexual assault. The high number of murder, rape, and child abuse cases has led to increased numbers of forensic cases being heard in courts. Analysis of the bite mark is the second major responsibility of the forensic dentist.
\end{abstract}

Keywords: Forensic dentistry; Age estimation; Bite mark analysis

\section{Introduction}

The term "forensic" is from the Latin, meaning forum or a place where legal matters are discussed [1]. The science of dentistry as related to the law is known as Forensic dentistry or Forensic odontology [2].

The theory behind forensic dentistry is that "no two mouths are alike" [3]. Forensic dentistry or forensic odontology involves dentists' participation in assisting legal and criminal issues. It refers to the proper handling, examination and evaluation of dental evidence, which will be then presented in the interest of justice [4].

Forensic identification by its nature is a multidisciplinary team effort relying on positive identification methodologies as well as presumption or exclusionary methodologies. Typically, this effort involves the cooperation \& coordination of law enforcement officials, forensic pathologists, forensic odontologists, forensic anthropathologists, serologists, criminalistics, \& other specialists as deemed necessary [5].

Forensic dentistry has become an integral part of forensic medicine over the past 100 years. This has been due to the dedication of people like Amoedo, Gustafson, Sognaes, Keiser-Nielsen and Suzuki, Whittaker, Clement, to name but a few. They established the essential role which forensic dentistry plays mainly in the identification of human remains [6].

\section{The Scope of Forensic Dentistry}

The major area of activity of forensic odontology is the identification of human beings, either dead or alive. This is more so in case of mass disaster, where the corpse is usually badly mutilated. Other areas of application include criminalistics, in cases involving abuse of children and elderly. Bite marks also help in detection of culprits. It also renders its service in probing of dental malpractice, archeology etc. [7].

The scope of forensic dentistry is broad \& ever-challenging. Each case is different \& even the seemingly routine case may test the dentist's ingenuity in applying his dental knowledge [8].

\section{Historical Background}

Forensic odontology has been with us since the beginning when, according to the Old Testament, Adam was convinced by Eve to put a 'bite mark' in apple [9].
The earliest dental identification began with the Agrippina and the Lollia Paulina case. Shortly after her marriage in the year 49 A.D to Claudius, Emperor of Rome, Agrippina, began plotting to secure her position. Because she feared that the rich divorcee Lollia Paulina might still be a rival for her husband, Agrippina soon decided that it would be safer if Lollia Paulina was dead. To be safer Agrippina sent her own soldiers to kill Lollia Paulina, the soldiers were further instructed to bring back her head. Cutting off the head after inflicting death was not uncommon in those days, the only positive proof of death being visual. Agripinna stared at the severed head, unable to recognize the distorted face; she parted the lips with her fingers looking for Lollia Paulinas teeth which were known to have certain distinctive characteristics. Only then was she satisfied that it was Lollia Paulina. It marks the first use of dental identification of which there is record [7].

It was used in the identification of Adolf Hitler and his wife Eva Brawn at the end of World War II.

In 1453 the first formally reported case of dental identification was that of the 80 years old warrior John Talbot, Earl of Shrews bury, who fell in the battle of Castillon [10].

Early in 1775 Revere constructed a silver wire fixed bridge for his close friend Dr. Joseph Warren, a medical practitioner. At the outset of the war, Warren refused the appointment of surgeon-in-chief to the continental army. Instead, he requested the rank of a line officer; Unfortunately, Warren was killed by a bullet that pierced his skull in the Battle of Bunker Hill

Buried by the British, ten months later, when the British had

${ }^{*}$ Corresponding author: Karanprakash Singh, BDS, MDS, Genesis Institute of Dental Sciences and Research, Ferozepur, India, Tel: +918437112344; E-mail: drkarankahlon@gmail.com

Received December 24, 2011; Accepted January 18, 2012; Published January 20, 2012

Citation: Singh K, Anandani C, Bhullar RK, Agrawal A, Chaudhary H, et al. (2012) Teeth and their Secrets - Forensic Dentistry. J Forensic Res 3:141. doi:10.4172/2157-7145.1000141

Copyright: (c) 2012 Singh K, et al. This is an open-access article distributed under the terms of the Creative Commons Attribution License, which permits unrestricted use, distribution, and reproduction in any medium, provided the original author and source are credited. 
evacuated Boston, Warren's brothers, Paul Revere, and friends sought to recover his body from its unmarked grave. Revere was able to identify the remains by the bridge work he had constructed.

Warren was reburied on April 8, 1776 in King's Chapel. Joseph Warren was the first person to be identified by a dentist.

The identification of John Wilkes Booth's body, recovered by union soldiers, was a controversial issue. The matter was resolved by the family doctor who was able to make a definite identification of dentition [7].

In 1897 a paper entitled, "The role of the Dentists in the identification of the victims of the catastrophe of the Bazar de la Charite, Paris and $4^{\text {th }}$ May, 1897", was presented by Dr. Oscar Amoedo (Professor of the dental school in Paris) at the international Medical Congress of Moscow. The bazar, at which the wealthy women of Paris annually raised money for projects for the poor, was destroyed within 10 minutes and 126 persons lost their lives.

The bodies of those killed in the fire were brought to the industrial place for identification. Visual identification was difficult because many were mutilated and extensively burned. Recognition was made by means of pieces of clothing and personal effects. When 30 remaining corpses could not be identified, the Paraguayan Consul suggested that the dentists of the missing persons be called to chart dentition and to identify the bodies by their dentition. The first treatise on forensic odontology was written by Dr. Oscar Amoedo in 1898 and was entitled L'Art Dentaire en Medicine Legale. Dr. Oscar is also known as father of Forensic Odontology [11].

In 1870, Ansil L Robinson was charged with the murder of his mistress; Mary Lunsford. Evidence against Robinson included an attempt to match his teeth to the bite marks on the victim's arm [12].

In 1937 in Chantilly, a murder was convicted on the evidence of the bite marks that the victim inflicted during her struggle for life [10].

Wayne Clifford Boden was a Canadian serial killer and rapist active from 1969-1971. He earned the nickname "the Vampire Rapist" because he had the penchant of biting the breasts of his victims, a method of operation that led to his conviction due to forensic odontological evidence [13].

The fire on board the "Scandinavian Star" was one of the world's worst ferry disasters. Dental identity could be established in 107 cases (68\%) [14].

Sager case involved the murder of a 14 year old girl. The state's evidence included comparison by forensic odontologists, of bite marks on the victim's body to the defendant's dentition. After a painstaking review of voluminous legal and dental authorities, the Missouri court determined that the science of positive bite mark identification has reached the level of scientific reliability and credibility to permit its admission as evidence in criminal proceedings [15].

Forensic odontologists successfully identified tsunami victims in South-East Asia in December 2004; more than 92\% of the non-Thai victims have been identified, out of which about $80 \%$ were identified by dental information. This high success rate of dental identification in Thailand was a matter of surprise for many forensic experts [16].

\section{Forensic Sciences Organizations}

There are three major forensic dental organizations on the North American Continent.
The American Society of Forensic odontology was organized at the Armed Forces Institute of Pathology (AFIP) in Washington, D.C in November, 1970, by Colonel Robert Boyers, the then chief of Dental \& oral pathology division of AFIP.

The Canadian Society of Forensic Science (CSFS) is a non-profit professional organization incorporated to maintain professional standards, and to promote the study and enhance the stature of forensic science. Membership in the society is open internationally to professionals with an active interest in the forensic sciences. It is organized into sections representing diverse areas of forensic examination: Anthropology, Medical, Odontology, Biology, Chemistry, Documents, Engineering, Firearms and Toxicology.

The American Academy of Forensic Sciences is a multi-disciplinary professional organization that provides leadership to advance science and its application to the legal system. The objectives of the Academy are to promote education, foster research, improve practice, and encourage collaboration in the forensic sciences [7].

\section{The Job of Forensic Odontologists}

As we enter a new millennium, our society is faced with fresh challenges in every conceivable area. Despite leaps in modern technology, medical breakthroughs and the geographical changes that the last century has brought, crime still persists in all aspects of our lives. Violent and heinous activities that shatter the lives of victims, their friends and families occur everyday. Often, little can be done to repair such damage. The apprehension and subsequent prosecution of the perpetrator(s) is essential to maintain law and order. Through the specialty of forensic odontology, dentistry plays a small but significant role in this process. By identifying the victims of crime and disaster through dental records, dentists assist those involved in crime investigation [5].

\section{Identification of the living or the deceased}

Dental identification of humans occurs for a number of different reasons and in a number of different situations [17]. Dental identifications have always played a key role in natural and manmade disaster situations and in particular the mass casualties normally associated with aviation disasters [18].

\section{Bite mark identification, analysis and comparisons}

The term 'bite mark' is used in this field knowing that the marks are the result of the tooth impression in different materials [19]. Bite marks can be found in flesh, foodstuffs and less frequently in a variety of other materials. The procedure for comparison of bite marks on the skin of victims to the dentition of possible assailants is well established and has been reported in historical cases, and in many cases to the present day. Since 1966 there have been more than 100 papers written on the subject, the majority of which are case reports or descriptions of technique. Bite mark evidence has recently become increasingly important in the investigation of non-accidental injuries to children [20].

\section{DNA analysis from saliva obtained from bite marks}

DNA analysis has been used successfully in a number of large accidents to associate body parts and for purposes of identification, by comparing victims' DNA profiles with those of relatives [4- 6]. However, DNA typing is still not generally regarded as an essential part of disaster victim identification [21]. 
Citation: Singh K, Anandani C, Bhullar RK, Agrawal A, Chaudhary H, et al. (2012) Teeth and their Secrets - Forensic Dentistry. J Forensic Res 3:141. doi:10.4172/2157-7145.1000141

\section{Dental age estimation}

The determination of D- and L-aspartic acid (Asp) content from teeth has been applied in age estimation for forensic purposes over the past decades. It was first introduced to assess age from tooth enamel and later from dentin and cementum. Recently, dentin seems to be most reliable, as the racemization reaction progresses more rapidly in the root than in the crown [22].

\section{Lip print identification, analysis \& comparison}

Cheiloscopy (from the Greek words cheilos, lips) is the name given to the lip print studies. The importance of cheiloscopy is linked to the fact that lip prints are unique to one person, except in monozygotic twins [23].

Lip prints can be instrumental in identifying a person positively and can be used to verify the presence or absence of a person at the scene of crime. The wrinkles and grooves on labial mucosa, called as sulci labiorum forms a characteristic pattern called as lip prints and the study of which is referred to as cheiloscopy [24].

\section{Rugae print identification, analysis \& comparison}

Dental evidence can be used as the sole method of identifying a deceased person. In circumstances where identification of an individual by fingerprint or dental record comparison is difficult, palatal rugae may be considered as an alternative source. Palatal rugae have been shown to be highly individual and consistency in shape throughout life. Hemanth et al. [25] evaluated the use of palatal rugae patterns for forensic identification in their study using manual method.

\section{Denture identification}

Labelled dentures can be of great assistance in the identification of individuals [26]. Unlabelled dentures have been recovered from patients and then fitted to casts retained by the treating dentist or laboratory, and this has been an accepted method of identification [27].

\section{Sex determination by DNA and teeth}

Sex is the first step of personal identification in forensic medicine. Recently, with advances in gene analysis techniques, methods for sex determination using $\mathrm{X}$ and $\mathrm{Y}$ chromosome DNA analysis have been developed [28].

\section{Conclusion}

Forensic dentistry plays a major role in identification of those individuals who cannot be identified. Recent tragedies and past and present situations have increased awareness concerning the importance of forensic dentistry in identification of victims.

To maximize dental application in forensic cases, it is necessary to train dentists in the practical aspects of forensic odontology. And there is necessity in exposing dentists to the basic principles and techniques of the subject.

Hence dependence on latest technologies alone does not always help in solving cases and reversion to the conventional method may be required. Thus a combination of reliable conventional methods and potentialities of advanced sciences can make wonders in the Science of Forensic Dentistry.

\section{References}

1. Puerini SJ (2005) Forensic odontology and the postmortem identification process. Med Health R I 88: 308-309.
2. Carol E, Henderson JD (2009) President's Editorial-AAFS and Forensic Science:The Next 60 Years.J Forensic Sci 54: 5-6.

3. Chowdhry A (2008) Forensic dentistry ... Past, Present, Future. Dentistry Zone com.

4. Deebaei A, Moghaddam HF, Delkhosh P (2008) The statistical analysis of application of teeth in forensic odontology center, Tehran, Iran,1980-2000. Pak J Med Sci 24: 48-51.

5. Pretty IA, Sweet D (2001) A look at forensic dentistry--Part 1: The role of teeth in the determination of human identity. Br Dent J 190: 359 -366.

6. Goharbabar M, Iqbal S, Jan A (2007) Essential Guidelines for forensic dentistry Pak. Oral Dental J 27: 79-84.

7. Luntz LL (1977) History of forensic dentistry. Dent Clin North Am 21: 7-17.

8. Standish SM, Stimson PG (1977) Scope of Forensic Dentistry. Dent Clin North Am 21: 3-5.

9. Gustafson G (1996) Forensic odontology. American Elsevier Publishing Co New York.

10. Rai B, Anand SC (2007) Palatal rugae: In forensic examination. J Forensic Med Toxi 5: $1540-2622$

11. Amoedo O L'Art Dentaire en Medecine Legale, Paris, MAssan Cie, Editeurs Libraires de L'Academie de Medecine, 1898.

12. Pierce LJ, Strickland DJ, Smith ES (1990) The case of Ohio v. Robinson. An 1870 bite mark case. Am J Forensic Med Pathol 11: 171-177.

13. http://en.wikipedia.org/wiki/Forensic_dentistry

14. Solheim T, Lorentsen M, Sundnes PK, Bang G, Bremnes L (1992) The "Scandinavian Star" Ferry disaster 1990 -a challenge to forensic odontology. Int J Leg Med 104: 339-345.

15. Bowers CM (2006) Forensic dental evidence an investigator's hand book. (1 ${ }^{\text {st }}$ edn), Elsevier Academic Press.

16. Schuller-Götzburg P, Suchanek J (2007) Forensic odontologists successfully identify tsunami victims in Phuket, Thailand. Forensic Sci Int 171: 204-207.

17. Weedn VW (1998) Postmortem identifications of remains. Clin Lab Med 18 115-137.

18. Brannon RB, Kessler HP (1999) Problems in mass disaster dental identification a retrospective review. J Forensic Sci 44: 123-127.

19. Lessig R, Wenzel V, Weber M (2006) Bite mark analysis in forensic routine case work. EXCLI Journal 5: 93-102.

20. Whittaker DK, Brickley MR, Evans L (1998) Comparison of the ability of experts and non experts to differentiate between adult and child human bite marks using receiver operating characteristic (ROC) analysis. Forensic Sci Int 92: 11-20.

21. Olaisen B, Stenersen M, Mevag B (1997) Identification by DNA analysis of the victims of the August 1996 Spitsbergen civil aircraft disaster. Nat Genet 15: 402-405.

22. Aranya S, Ohtani S, Yoshioka N, Gonmori K (2004) Age estimation from aspartic acid racemization of root dentin by internal standard method. Forensic Sci Int 141: 127-130.

23. Caldas IM, Magalhaes T, Afonso A (2007) Establishing identity using cheiloscopy and palatoscopy. Forensic Sci Int 165: 1-9.

24. Sharma P, Saxena S, Rathod V (2009) Cheiloscopy: The study of lip prints in sex identification. J Forensic Dent Sci 1: 24-27.

25. Hemanth M, Vidya M, Shetty N, Bhavana KV (2010) Human identification using palatal rugae: Manual method. J Forensic Dent Sci 2: 86-90.

26. Marella GL, Rossi P (1999) An approach to identification by means of denta prostheses in a burnt corpse. J Forensic Odontostomatol 17: 16-19.

27. Jacob RF, Shalla CL (1987) Postmortem identification of the edentulous deceased denture tissue surface anatomy. J Forensic Sci 32: 698-702.

28. Murakami H, Yamamoto Y, Yoshitome K, Ono T, Okamoto O, et al. (2000) Forensic study of sex determination using PCR on teeth samples. Acta Med Okayama 54: 21-32. 